\title{
Physical property evolution of granite during experimental chemical stimulation
}

\author{
Jamie I. Farquharson ${ }^{1 *}$, Alexandra R. L. Kushnir ${ }^{2}$, Bastien Wild ${ }^{3}$ and Patrick Baud ${ }^{2}$
}

\author{
*Correspondence: \\ jifarq89@googlemail.com \\ ${ }^{1}$ Rosenstiel School of Marine \\ and Atmospheric Sciences, \\ University of Miami, 4600 \\ Rickenbacker Causeway, \\ Miami, FL 33149, USA \\ Full list of author information \\ is available at the end of the \\ article
}

\begin{abstract}
The Soultz-sous-Forêts geothermal reservoir (France) — in particular, the GPK-4 wellhas been proposed as a target for chemical stimulation under the DESTRESS Horizon-2020 framework. With a combination of batch reaction tests and acid flow-through experiments using hydrochloric acid $(\mathrm{HCl})$ at different molarities and temperatures, we investigate the potential for acid-induced permeability enhancement of a granite analogous to the Soultz-sous-Forêts reservoir rock, by means of acid stimulation. In the batch reaction experiments, we find that the propensity for increase or decrease in porosity and permeability depends on the physico-chemical properties of the starting material: unaltered granite underwent a significant increase in both porosity and permeability relative to its initial state, altered granite exhibited a moderate increase in both porosity and permeability (modulated slightly by $\mathrm{HCl}$ molarity), whereas initially more porous and permeable thermally and naturally fractured granite exhibited an increase in porosity accompanied by a relative decrease in permeability. The extent to which permeability increased or decreased appears to be tied to the initial fluid-flow characteristics of the material. Using a new, custom-built acid permeameter, flowthrough tests were performed on unaltered granite, while the acid was sampled at regular time intervals. Element release into solution recorded throughout the experiments, indicated dissolution of granite minerals. Despite this operative micromechanism, however, the absolute change in sample permeability is limited, both at room temperature and at $100^{\circ} \mathrm{C}$. Ultimately, these data suggest that the potential for geothermal reservoir enhancement using $\mathrm{HCl}$ is low at Soultz-sous-Forêts. Nevertheless, the possibility remains that a more targeted thermal or chemical stimulation approach—or hybrid thereof-could prove effective in the future.
\end{abstract}

Keywords: Geothermal, Granite, Dissolution, Soultz-sous-Forêts, Permeability, Porosity, Hydrochloric acid

\section{Introduction}

Fundamentally, geothermal energy is heat energy stored within the Earth, comprising approximately equal parts primordial heat (from the formation of the planet) and heat generated by the decay of radiogenic isotopes KamLAND Collaboration (2011). Humankind has been exploiting this thermal energy since at least 11,000 BCE (Sekioka 1999), when hot springs were used for balneotherapy (the treatment of disease by bathing) as well as bathing more generally. Since the Paleolithic, we have 
learned to harness the Earth's heat for geothermal heating and, since the early 1900s (Fridleifsson et al. 2008), electricity generation.

Conventional geothermal technology involves the generation of energy from natural sources of hot water or steam (e.g. Duchane and Brown 2002). However, the majority of accessible geothermal energy is to be found in more-or-less intact, low-permeability reservoirs lacking mobile water (Duchane and Brown 2002). In the last three decades, a great deal of research has been focussed towards the exploitation of these reservoirs at depths greater than around $3 \mathrm{~km}$ and temperatures above $150^{\circ} \mathrm{C}$ (Tester et al. 1989, 2006).

Enhanced Geothermal System (EGS) projects seek to exploit heat at depth through reservoir stimulation. Productivity of a geothermal well may be enhanced by increasing the transmissivity of existing fracture networks-or by creating new fractures-by means of thermal, hydraulic, or chemical stimulation (e.g. Portier et al. 2009). EGSs have tremendous potential for improving the efficiency of primary energy recovery from geothermal systems (Fridleifsson 2001). Modelled and experimental fluidrock interactions (e.g. Rose et al. 2007; Flores et al. 2005) suggest that such reservoir enhancement could be highly productive, and this has been borne out in on-site studies. At a geothermal research well at Groß Schönebeck (Germany), for example, a campaign of hydraulic and chemical stimulation was shown to increase well productivity by a factor of $\sim 6$ (Zimmermann et al. 2011).

The site at Soultz-sous-Forêts, France, is an experimental and industrial geothermal site situated within the Upper Rhine Graben above a strong thermal anomaly (e.g. Schellschmidt and Clauser 1996; Pribnow and Schellschmidt 2000; Bächler et al. 2003; Freymark et al. 2017). The ongoing project was the first site in France to be characterised as an EGS (Gérard et al. 2006; Genter et al. 2013). The system comprises a variably fractured granitic reservoir with a large circulating volume of highly saline brine (Genter et al. 2010). The granitic reservoir is overlain by a series of Permo-Triassic sedimentary units: the Buntsandstein (e.g. Heap et al. 2017; Kushnir et al. 2018), the Muschelkalk (e.g. Heap et al. 2019), and the Keuper (e.g. Aichholzer et al. 2016), which themselves are important for regional heat and fluid flow and exchange (e.g. Ledésert et al. 1996; Aquilina et al. 1997). The geothermal plant is located between the Alsacian communes of Soultz-sous-Forêts and Kutzenhausen, approximately $70 \mathrm{~km}$ north of Strasbourg (Fig. 1a), and consists of four deep wells (GPK-1, GPK-2, GPK-3, GPK-4) and a partially cored exploration well (EPS-1) (Dezayes et al. 2005; Genter et al. 2010). Of these, three are set up as a triplet, with GPK-3 being used for central injection and the neighbouring GPK-2 and GPK-4 wells used for production (e.g. Nami et al. 2008).

A key concern in the pursuit of reservoir enhancement is the increased incidence of induced seismicity often associated with the generation or widening of fractures. Acid stimulation comprises a so-called "soft-stimulation" treatment, whereby some combination of acids, chelating agents and/or retarding agents are injected or otherwise introduced into the open-hole section of a geothermal well, with the ultimate aim 


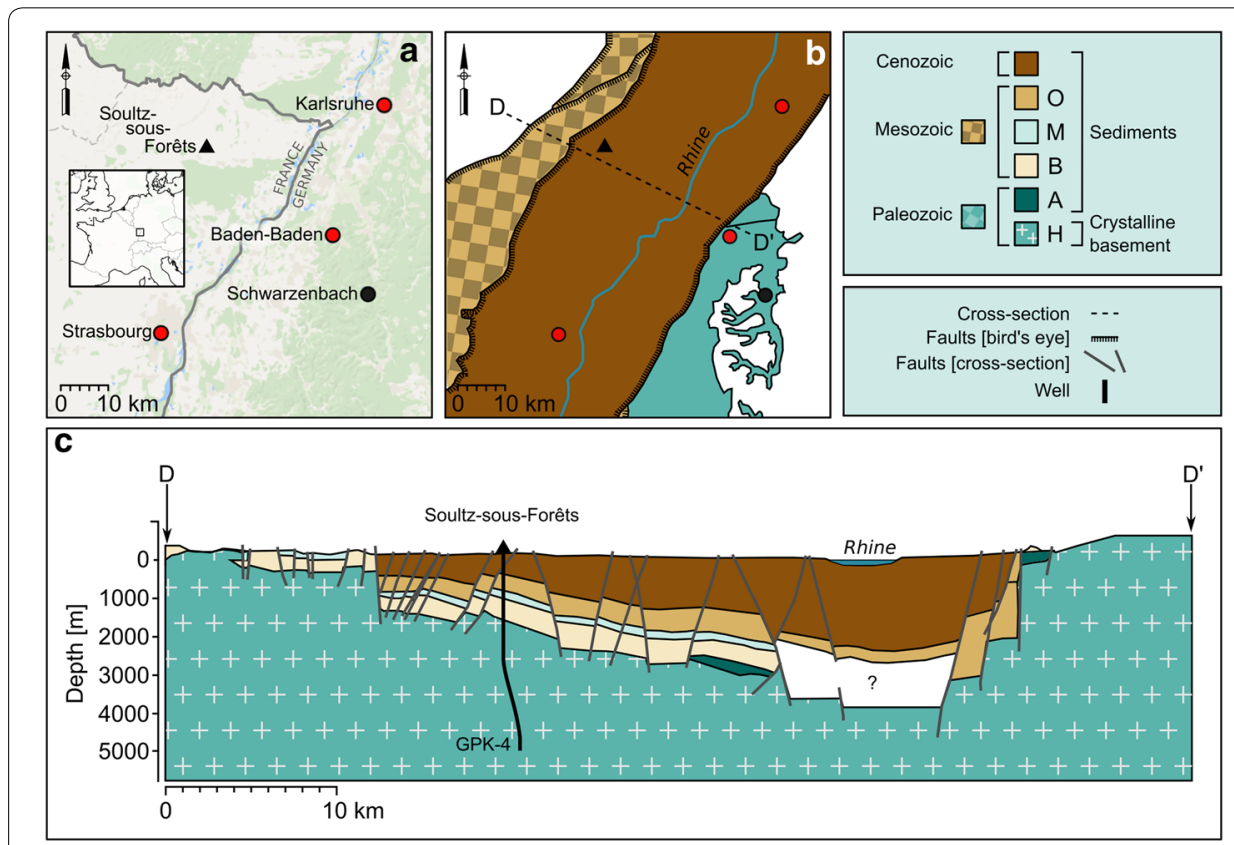

Fig. 1 Site and geological maps of study area. a Location map of Soultz-sous-Forêts geothermal site with respect to nearby cities (red circles) and Schwarzenbach sampling site (black circle). b Simplified geological map of the area shown in $\mathbf{a}$, indicating location of cross-section shown in c. Modified after Dezayes et al. (1995) and Stober and Bucher (2015). c Geological cross-section of the Upper Rhine Graben region, modified after Stober and Bucher (2015) and Aichholzer et al. (2016). The open-hole section of the GPK-4 well is situated in the Hercynian (Variscan) crystalline basement. Geological unit abbreviations: $\mathrm{H}=$ Hercynian basement; $\mathrm{A}=$ anté-Annweiler; $\mathrm{B}=$ Buntsandstein; $\mathrm{M}=$ Muschelkalk; $\mathrm{O}=$ other mesozoic sediments

of increasing permeability of the rock mass whilst avoiding the generation of detectable seismicity. Under the auspices of the DESTRESS ${ }^{1}$ Horizon-2020 framework, the GPK-4 well at Soultz-sous-Forêts is a target for enhancement through acid stimulation. This contribution examines the feasibility of such a campaign from an experimental standpoint, by exploring influence of different acid treatments on granite under a range of temperature conditions. Specifically, we investigate how the physical (porosity, permeability, mass) and mechanical (compressive strength, Young's modulus) properties of granite may evolve over time, when exposed to different acid environments. We use chemical and microstructural analyses to interpret the operative mechanisms at work during our experiments.

\section{Materials and methods}

\section{Sample collection and characterisation}

Due to detailed interpretations of drill cores, cuttings, and geophysical data from the Soultz-sous-Forêts wells, a fairly detailed geological model of the geothermal reservoir has been established (e.g. Gérard et al. 2006; Sausse et al. 2006; Dezayes et al. 2010; Sausse et al. 2010; Aichholzer et al. 2016). In Fig. 1b and c, we summarise the main geological features of the site pertinent to this study: the geological map and cross-section are based on the work of Dezayes et al. (1995), Stober and Bucher 

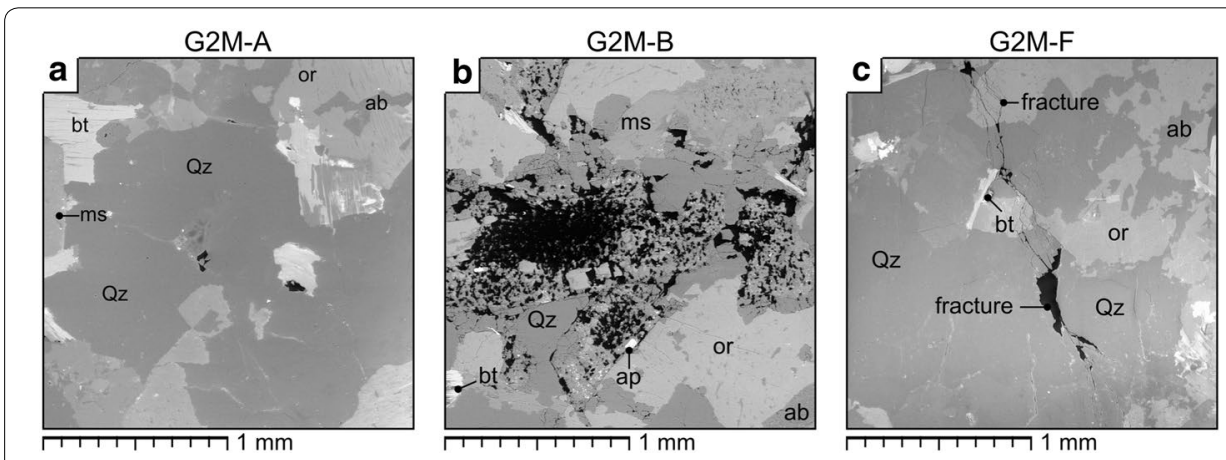

Fig. 2 Three classifications of granite collected at Schwarzenbach (Fig. 1). a-c Scanning electron microscope images of examples from each suite ( $G 2 M-A, G 2 M-B$, and $G 2 M-F$, respectively). Minerals identified using $X$-ray powder diffraction and energy-dispersive X-ray microanalysis: $\mathrm{Qz}=$ quartz; or = orthoclase; $\mathrm{ab}=$ albite; $\mathrm{bt}=$ biotite; $\mathrm{ms}=$ muscovite; $\mathrm{ap}=$ apatite

(2015), and Aichholzer et al. (2016). Cenozoic, Mesozoic, and Paleozoic sediments overlie a massive porphyritic granite (Gérard et al. 2006), in turn overlying another biotite- and amphibole-rich granite, below which-at around $4.7 \mathrm{~km}$ depth-is an intrusion of relatively younger fine-grained two-mica granite (e.g. Aichholzer et al. 2016), dated between around 338 and $330 \mathrm{Ma}$ (Cocherie et al. 2004).

Unfortunately, the size of cuttings recovered from the GPK-4 well is generally too small to obtain suites of centimetric laboratory samples required for our experimental investigations. Instead, we sampled granites from a site close to the Schwarzenbach Dam in Germany (Fig. 1a) where the crystalline basement underlying the Soultzsous-Forêts plant is outcropping and accessible (Fig. 1c). We collected a number of large blocks from which to obtain nominally homogeneous sample suites.

The variably altered granites contain muscovite and biotite-determined by X-ray powder diffraction (XRD) and energy-dispersive X-ray microanalysis (EDX)-and appear to be an ideal analogue for the two-mica deep reservoir material at Soultzsous-Forêts. Many of the granites were found to host macroscopic fractures. Although previous studies have identified fractures in the Soultz basement that host illite and calcite (e.g. Ledésert et al. 1996; Hébert et al. 2010; Ledésert et al. 2010; Meller and Ledésert 2017), we were unable to confirm the presence of either mineral through XRD or EDX analyses. Nevertheless, we cannot discount the possibility that these carbonate and clay minerals are indeed present-albeit in very low abundancein these granites.

Samples were divided into three suites for experimentation, based initially on their appearance in their field and refined with the use of scanning electron microscope (SEM) and EDX analyses (shown in Fig. 2):

- a fine-grained leucocratic two-mica granite (G2M-A): pale grey in hand sample;

- a slightly hydrothermally altered granite containing additional secondary minerals such as apatite (G2M-B): visibly altered and yellow-grey in hand sample;

- an unaltered granite identical to G2M-A, but containing abundant macroscopic fractures (G2M-F). 
Table 1 Mineral content of G2M-A granite in wt.\% from XRD analysis

\begin{tabular}{lc}
\hline Quartz & $37 \pm 2$ \\
K-Feldspar & $28 \pm 2$ \\
Microcline & $12 \pm 2$ \\
Orthoclase & $16 \pm 2$ \\
Albite (plagioclase) & $24 \pm 2$ \\
Biotite & $4 \pm 1$ \\
Muscovite/illite & $5 \pm 1$ \\
Chlorite & $2 \pm 1$ \\
Total & 100 \\
\hline
\end{tabular}

XRD data for G2M-A are given in Table 1. Scanning electron microscope images of each category of granite are shown in Fig. 2. Cylindrical samples were cored from the collected blocks, with a diameter of $20 \mathrm{~mm}$. Samples were sawn and precision-ground to a nominal length of $40 \mathrm{~mm}$. After drying samples at $40^{\circ} \mathrm{C}$ for $>48 \mathrm{~h}$ under a vacuum, their physical properties-mass, porosity, permeability-were measured.

Mass was measured with a precision balance. Helium pycnometry was then used to measure bulk sample volume $\left(V_{\mathrm{PYC}}\right)$ which we convert to porosity $\phi$, such that $\phi=\left(V_{\mathrm{GEO}}-V_{\mathrm{PYC}}\right) / V_{\mathrm{GEO}}$, where $V_{\mathrm{GEO}}$ is the geometric sample volume, calculated from dimension measurements performed with digital calipers.

Initial gas permeability measurements (i.e. permeability prior to any acid stimulation or thermal stressing of the samples) were performed using a modified benchtop permeameter at Université de Strasbourg (see Farquharson et al. (2016) for a schematic), using the pulse decay method (Brace et al. 1968). We summarise the method here, but for a detailed description of the measurement method and the calculation of permeability the reader is referred to Heap et al. (2017). With this method, permeability $k$ is determined by monitoring the equilibration of pore pressure (using nitrogen gas as a permeant: nominally inert relative to the sample material) across a sample of length $L$ between two reservoirs of known volume. The upstream reservoir has pressure and volume $p_{\mathrm{u}}$ and $V_{\mathrm{u}}$, respectively, while the downstream reservoir (of pressure $p_{\mathrm{d}}$ and volume $V_{\mathrm{d}}$ ) is at atmospheric pressure and nominally infinite volume (i.e. $p_{\mathrm{d}}=p_{\mathrm{atm}}$ and $\left.V_{\mathrm{d}}=\infty\right)$, as the gas is vented to ambient laboratory conditions. We increase $p_{\mathrm{u}}$ to a set point (typically around $0.2 \mathrm{MPa}$, i.e. $2000 \mathrm{mbar}$ ) for 1 hour, in order to ensure saturation of the sample with nitrogen. After this stage, the upstream reservoir is isolated from the sample by a valve, and $p_{\mathrm{u}}$ is allowed to decay towards $p_{d}$ (i.e. $p_{\mathrm{atm}}$ ). If we define $p_{\mathrm{f}}$ as the final, equilibrated pore pressure within the sample, then this decay can be described by:

$$
p_{\mathrm{u}}-p_{\mathrm{f}}=\Delta p\left(\frac{1}{V_{\mathrm{u}}}+V_{\mathrm{d}}\right) \exp ^{-\alpha t}
$$

where $\Delta p=p_{\mathrm{u}}-p_{\mathrm{d}}, t$ is time, and $\alpha$ is given by

$$
\alpha=\frac{k_{\infty} A}{\mu \beta L}\left(\frac{1}{V_{\mathrm{u}}}-\frac{1}{V_{\mathrm{d}}}\right) .
$$

The cross-sectional area of the sample is given by $A$, and the viscosity and compressibility of the pore fluid are given by $\mu$ and $\beta$, respectively. The permeability $k_{\infty}$ refers to 
the as-measured value (i.e. calculated under the assumption that flow is laminar within the samples and that no gas slippage or turbulent flow occur). After accounting for the non-constancy of gas compressibility (Heap et al. 2017), this expression ultimately becomes:

$$
k_{\infty}=\left[\frac{2 L \mu}{A}\right]\left[\frac{V_{\mathrm{u}}}{p_{\mathrm{u}}^{2}-p_{\mathrm{d}}^{2}}\right]\left[\frac{\mathrm{d} p_{\mathrm{u}}}{\mathrm{d} t}\right] .
$$

As described in Farquharson et al. (2017a) and Heap et al. (2017), the occurrence of gas slippage is tested for and incorporated using the ancillary correction of Klinkenberg et al. (1941) (see also McPhee and Arthur 1991):

$$
k=k_{\infty}\left(1+\frac{b}{\bar{p}}\right) ; \bar{p}=\left(\frac{\mathrm{d} p_{\mathrm{u}}+2 p_{\mathrm{d}}}{2}\right)
$$

such that $k$ is the "true", Klinkenberg-corrected permeability, $\bar{p}$ is the mean flow pressure of gas in the system, and $b$ is the Klinkenberg parameter, dependent on properties of the gas and the pore structure.

Table 2 gives the (initial) physical property data of the samples tested in this study. Uncertainty in the determination of permeability is estimated to be $\pm 1 \%$ based on the transducer resolutions on the equipment and the range of data selected for analysis. Uncertainty in the porosity measurements is calculated from the reported variability of repeat pycnometer measurements and error arising from manual measurements of sample dimensions (refer to Farquharson et al. (2017a) for more detail), and was found to be in the range $\pm 0.0005-0.0058$. Repeat measurements of mass yielded no variability at the resolution of the balance $( \pm 0.001 \mathrm{~g})$. P-wave velocities are calculated from three repeat travel-time measurements: propagated error based on this uncertainty is typically 0 and at most $0.58 \mathrm{~m} \mathrm{~s}^{-1}$.

\section{Mechanical testing}

Uniaxial compression experiments were performed on selected samples in order to constrain the potential evolution of rock strength with prolonged exposure to acid (immersion or stimulation). Deformation was carried out on samples saturated with distilled $\mathrm{H}_{2} \mathrm{O}$ using either of two apparatus at the Universite de Strasbourg. For schematics of the uniaxial and triaxial deformation rigs, the reader is referred to Heap et al. (2014) and Farquharson et al. (2017a), respectively. (For the purposes of this study, both apparatus are functionally the same). Saturated samples were deformed at a constant strain rate of $10^{-5} \mathrm{~s}^{-1}$ in a water bath at room temperature. Young's modulus $E$ was obtained from the uniaxial stress-strain data, taken as the slope of the curve within the linear elastic portion of the curve.

\section{Thermal treatment}

To explore the role of temperature on the transport properties of the Schwarzenbach granite, selected samples were subject to thermal treatment. Samples were heated in a Thermolyne 48000 furnace at a constant rate of $1{ }^{\circ} \mathrm{C} \mathrm{min}^{-1}$ to a target temperature, whereafter it dwelt at the set temperature for 120 minutes before being allowed to cool 


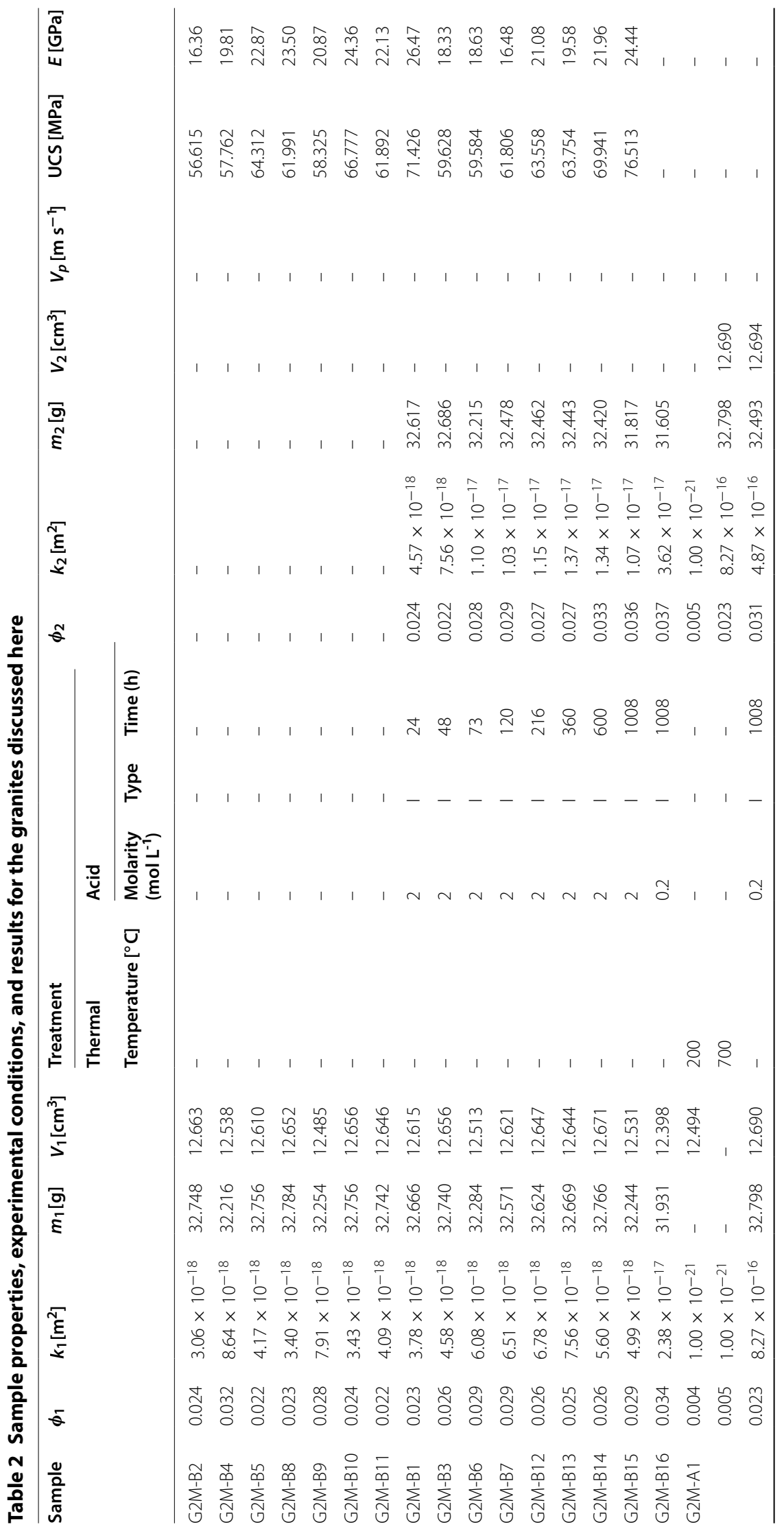




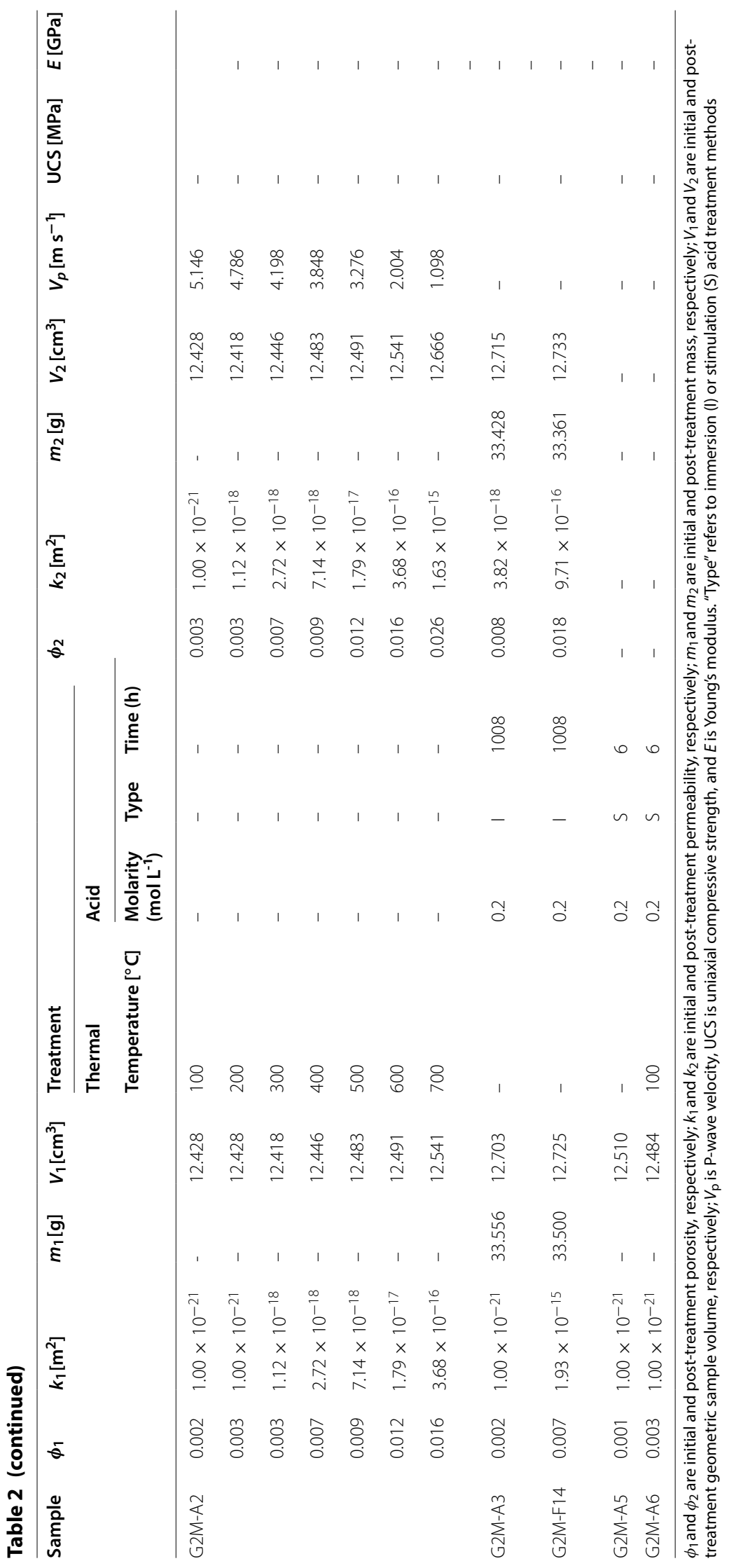


to ambient temperature. In some cases, this treatment was performed in heating/cooling cycles, with iteratively higher target temperatures being achieved each time. At room temperature, between each thermal stress cycle, physical properties of the granite were measured as described above. In addition, static measurements of P-wave velocity $v_{\mathrm{p}}$ were performed at room temperature on the thermally stressed samples. The setup comprises a pair of piezo-transducers mounted in a frame such that the transducers are in contact with either end of the sample. A $700-\mathrm{kHz}$ sinusoidal pulse is transmitted through the sample and P-wave velocities are calculated from the direct wave arrival time (observed using an oscilloscope).

\section{Acid properties}

Throughout this study, solutions of hydrochloric acid $(\mathrm{HCl})$ were used, without any additive agents such as corrosion inhibitors, chelating agents, or retardants. With a known formula weight $\left(36.46 \mathrm{~g} \mathrm{~mol}^{-1}\right)$ and density $\left(\rho=1180 \mathrm{~kg} \mathrm{~m}^{-3}\right)$, an initial starting solution of $37 \%$ extra pure $\mathrm{HCl}$ (CAS number: 7647-01-0) was diluted to 2.0 or $0.2 \mathrm{M}$ (depending on the experiment) using deionised $\mathrm{H}_{2} \mathrm{O}$.

\section{Acid immersion}

The time-dependent effects of acid stimulation were investigated via a series of simple batch reactor experiments. Samples were placed in a stainless steel wireframe basket, which was itself immersed in an acid solution at room temperature. Figure 3 shows a schematic of the setup. The acid solutions were kept in constant motion using a magnet and magnetic agitator, as illustrated in the figure. Periodically, samples were removed and their physical properties remeasured. Experimental parameters (pre- and post-stimulation physical properties, acid molarity, and immersion time) are given in Table 2.

\section{Acid stimulation}

An acid-resistant permeameter was custom-designed and constructed at the Université de Strasbourg in order to measure the influence of aggressive permeants over a range of relevant pressures and temperatures. The permeameter, illustrated in Fig. 4, comprises a pressure vessel-a standard NX-size stainless steel Hoek cell—connected to a Quizix QX1500 two-cylinder fluid pump from Chandler Engineering. Intermediate valves and tubing are rated to high temperatures and pressures. Confining pressure is applied by high-temperature silicone thermofluid ("temperieröl") using a two-stage manual hand pump, up to a maximum of $70 \mathrm{MPa}$. The pressure vessel is wrapped in high-temperature $\mathrm{AMOX}^{\mathrm{TM}}$ fabric tapes, and the whole ensemble is enclosed in a bespoke clamshell jacket (from HTS/Amptek). This jacket is composed of layers of mechanically bonded glass fibre matting (Tempmat), fibreglass cloth, and silicone-impregnated fibreglass cloth, which insulates the pressure vessel effectively due to the low thermal conductivity of the constituent materials. The $\mathrm{AMOX}^{\mathrm{TM}}$ tapes are plugged into a power strip, in turn connected to a programmable PID temperature controller. The controller reads temperature from a thermocouple embedded beneath the insulating jacket, and the power output to the heat tapes is adjusted accordingly in order to heat the pressure vessel to the desired (user-set) temperature. Within the pressure vessel, temperieröl surrounds a flanged seal, 


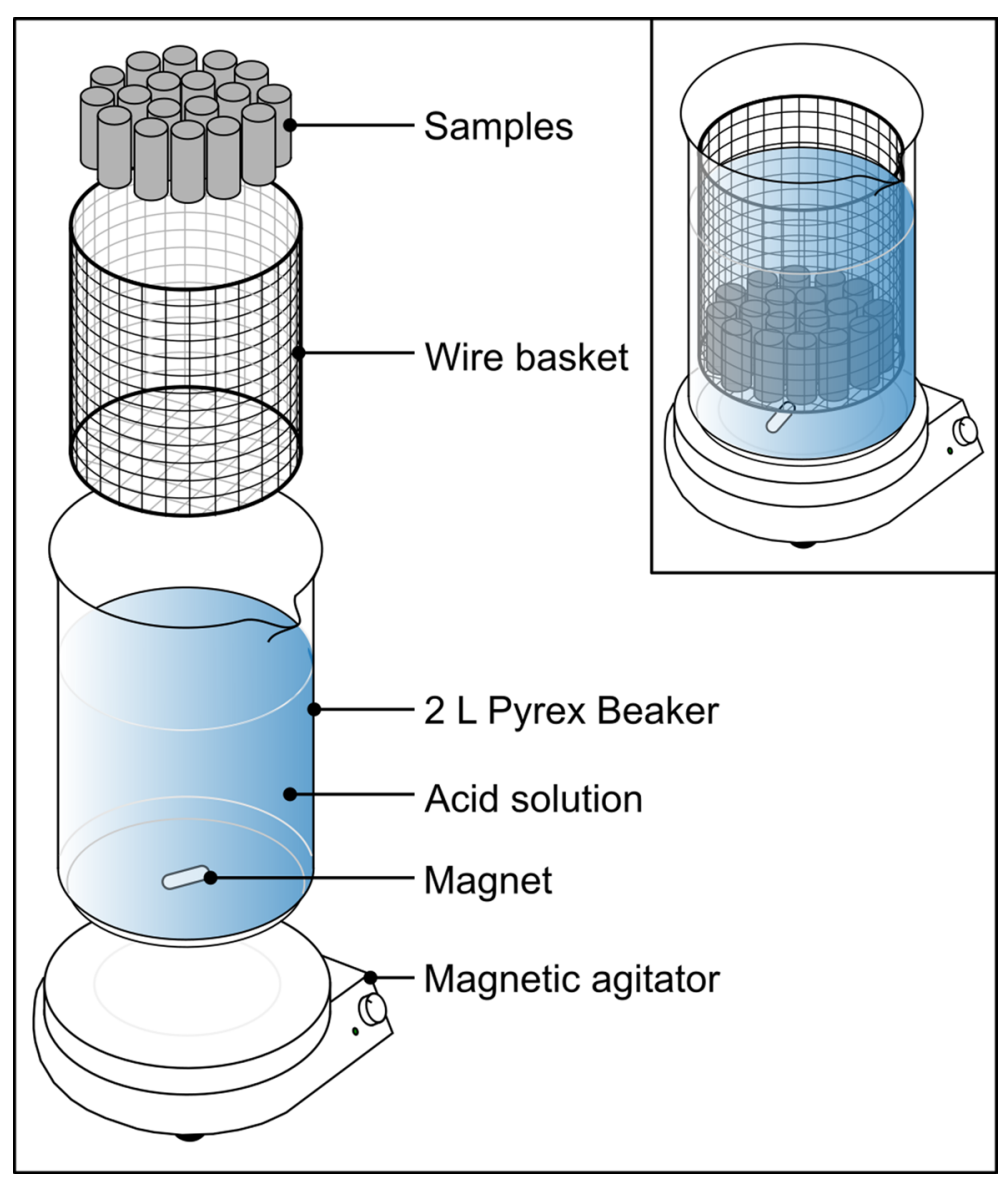

Fig. 3 Schematic of batch acid immersion experimental setup

custom-moulded from temperature- and acid-resistant rubber. The sample and spacers are inserted into the seal as illustrated in Fig. 4c.

A second thermocouple is in contact with the sample, in this case a mineral insulated $k$-type probe coated in Halar, an acid-resistant copolymer of ethylene and chlorotrifluoroethylene. Temperatures of the sample and vessel exterior are recorded using a National Instruments NI-9215 voltage input module integrated into a custom-built data acquisition hub (Fig. 4). The acquisition hub communicates with a program written in LabVIEW, which is also used to send commands and receive flow rate, pore pressure, and fluid volume data from the Quizix pump.

After mounting a sample between two spacers within the annular sleeve, the sleeve is slotted into the pressure vessel (Fig. 4c). When the endcaps are tightened, the flanged ends of the annular sleeve sit flush against silicone gaskets inside either endcap, ensuring an effective seal for the surrounding temperieröl. Using the manual pump (Fig. 4), a radial confining pressure of $1 \mathrm{MPa}$ is applied to the sample. Thereafter, the sample is left under these conditions until the recorded confining pressure signal stabilises (a function of the pressure applied, ambient temperature variations, and sample microstructure). At low confining pressures $(<5 \mathrm{MPa})$, this typically took around $1 \mathrm{~h}$. 

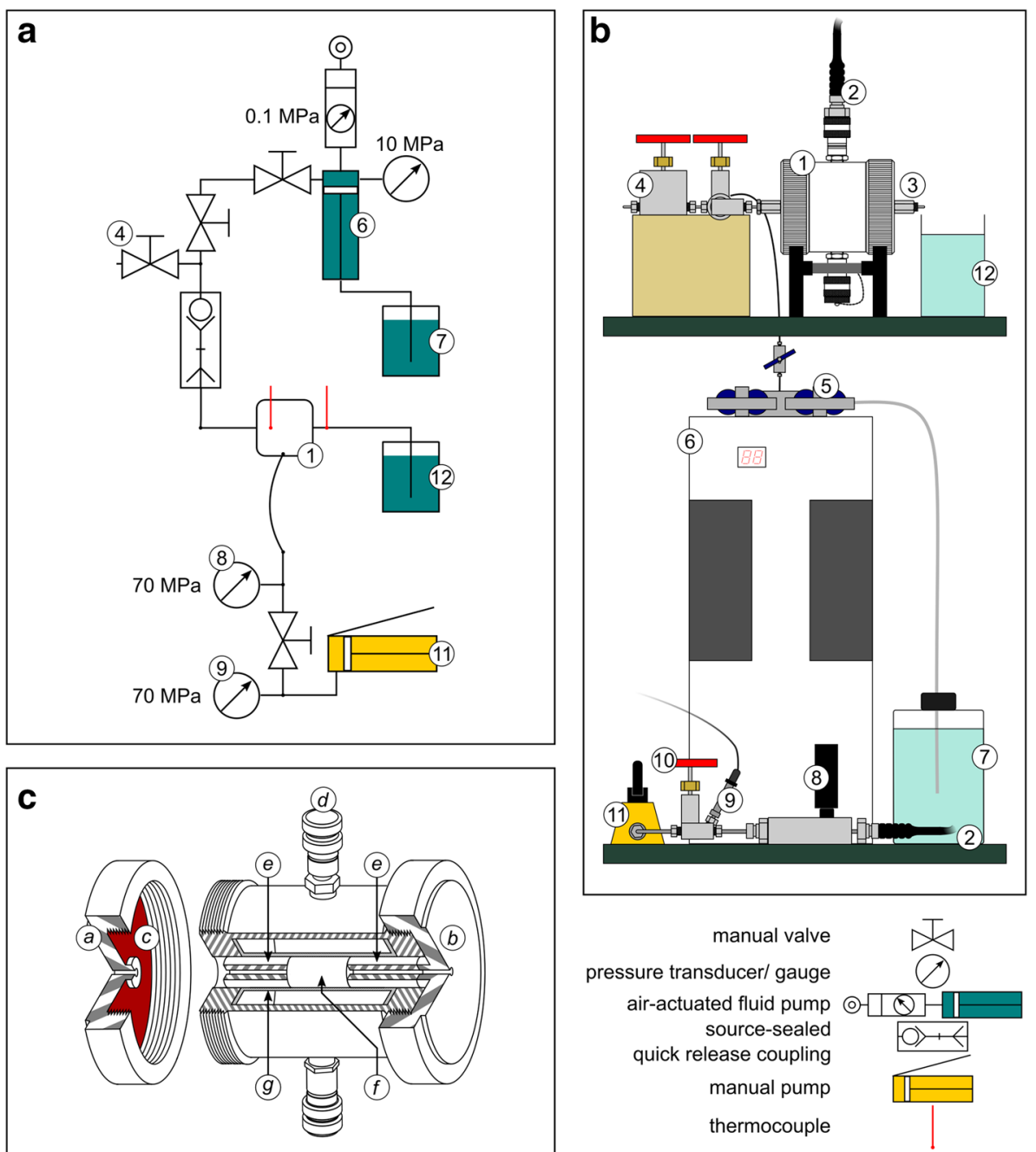

Fig. 4 Schematic of acid permeameter. a Technical diagram of permeameter circuit. b Sketch of primary components. c Diagram of pressure vessel interior. (1): pressure vessel; (2): confining pressure inlet/outlet; (3): pore fluid outlet; (4): vent valve; (5): pore fluid inlet/outlet ports; (6): Quizix pore fluid pump; (7): permeant reservoir; (8): pressure gauge; (9): analogue pressure transducer; (10): confining pressure outlet valve; (11): confining pressure pump/oil reservoir; (12): effluent reservoir. (a): upstream endcap; (b): downstream endcap; (c): silicone gasket; (d): confining pressure inlet/outlet; (e): steel spacers; (f): sample; (g): annular sleeve

After confining pressure equilibration, permeant flow through the system was instigated using the LabVIEW program written for this purpose. Once effluent fluid was observed exiting the pressure vessel at a constant rate, the output flow rate of the Quizix pump was adjusted to a constant rate and the evolution of the upstream pore pressure was recorded. If permeability was being measured at a single confining pressure, a range of flow rates were imposed (between 0.1 and $10 \mathrm{~mL} \mathrm{~min}^{-1}$ ), with the upstream pressure $p_{\mathrm{u}}$ being monitored at each rate step. The system is open on the downstream end to ambient conditions (i.e. room temperature and atmospheric pressure), so the pressure differential across the sample may be given by $\Delta p=p_{\mathrm{u}}-p_{\mathrm{atm}}$. Using Darcy's law, permeability is given by: 


$$
k=\frac{Q \mu L}{A \Delta p},
$$

where the parameters are as previously defined (subsection 2.1). Multiple steps (flow rates) were imposed in order to assess whether auxiliary corrections were required (i.e. to check for cases where flow was non-laminar). In practice, we found that $1 \mathrm{~mL} \mathrm{~min}^{-1}$ yielded laminar flow conditions for all the samples of this study.

Equation 5 assumes that the temperature in the pore fluid reservoir (in our setup, upstream of the sample) is equivalent to that of the sample. However, for some of our experiments, this condition is not true: the fluid in the reservoir, pump, and tubing are at ambient (room) temperature, whereas the sample temperature can vary, in this case up to $100^{\circ} \mathrm{C}$. Kushnir et al. (2017) describe the required correction (after Morrow et al. 2001) in order to account for this disparity. For a system where the volumetric flow rate $Q$ is measured at ambient temperature and pressure, the volumetric flow rate at elevated pressure and/or temperature $Q^{\prime}$ may be described by $Q^{\prime}=Q \times \varrho$, where $\varrho=\rho / \rho^{\prime}$ is the ratio of pore fluid density under ambient conditions $\rho$ and the fluid density at pressure and temperature $\rho^{\prime}$. Clearly, if the reservoir and sample temperatures and pressures are the same, then $\varrho$ reduces to unity, and $Q^{\prime}=Q$. Thus, we can now show permeability under any temperature and pressure condition as:

$$
k=\underbrace{[Q \varrho]}_{6 a} \underbrace{\left[\frac{\mu^{\prime} L}{A \Delta p}\right]}_{6 b},
$$

such that Eq. 6a accounts for the temperature-dependence of the volumetric flow rate (a system-scale parameter) and the components in Eq. 6b are sample-scale parameters (i.e. $\mu^{\prime}$ is the dynamic pore fluid viscosity at the elevated temperature and pressure of the fluid in the sample: see Farquharson et al. 2017b; IAPWS 2008). In our experimental setup there is a thermocouple in contact with the sample at the fluid outlet, meaning that the recorded sample temperature is equivalent to the effluent fluid temperature under steady-state conditions. Additionally, the time required for saturation of the sample with pore fluid can be approximated using the Darcy timescale $\lambda$, which is also derived from Darcy's law (e.g. Heap and Wadsworth 2016):

$$
\lambda=\frac{\mu^{\prime} L^{2}}{k \Delta p} .
$$

Fluid flow was initiated for $t \gg \lambda$ in order to ensure sample saturation prior to the onset of the experiments. Both fluid density and fluid viscosity are dependent on the pressure and temperature conditions under which our experiments were carried out. As such, values of $\rho^{\prime}$ and $\mu^{\prime}$ for each $p-T$ step are calculated ex post facto and used to correct the permeability data.

\section{Fluid chemistry}

To supplement the physical property measurements collected during acid flow-through tests, aliquots of the effluent fluid were collected at periodic intervals $(0,4000,8000$, 16000 , and 20000 s; i.e. $0-5.6 \mathrm{~h}$ ) during these experiments. Inductively coupled plasma 

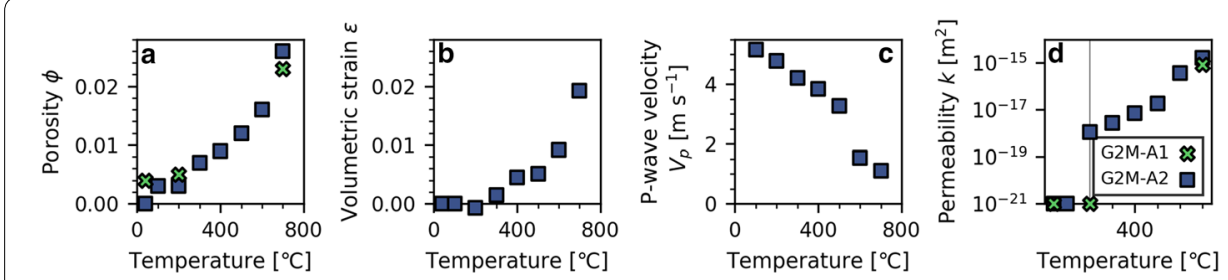

Fig. 5 Physical property evolution of G2M-A granite sample through iterative heating cycles. a Porosity evolution with heat treatment. b Volumetric strain evolution. c P-wave velocity decrease with heating. $\mathbf{d}$ Permeability change with heating. Vertical line highlights the onset of detectable permeability

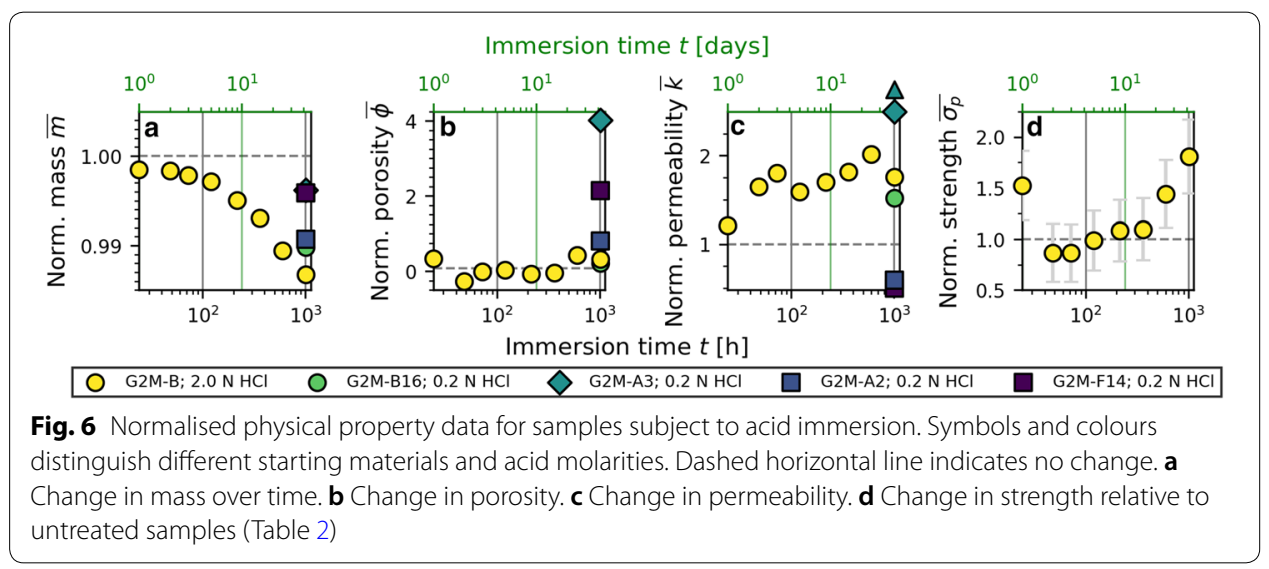

atomic emission spectroscopy (ICP-AES) was used to determine element concentrations in the fluid, in order to assess any chemical dissolution mechanisms occurring during stimulation.

\section{Results}

\section{Evolution of physical properties with temperature}

Two samples (G2M-A1 and G2M-A2) were subject to cycles of heating and cooling at a constant rate to incrementally higher temperatures. Data are given in Table 2 and Fig. 5. Sample porosity (Fig. 5a) and volume (Fig. 5b) exhibit a clear increase with respect to increasing temperature (from 0.002 to 0.026 and 12.428 to $12.666 \mathrm{~cm}^{3}$, respectively), with a concomitant decrease in P-wave velocity from 5.1 to $1.1 \mathrm{~m} \mathrm{~s}^{-1}$ (Fig. 5c). Klinkenberg-corrected gas permeability remained constant in both samples until the sample experienced treatment temperatures of $200^{\circ} \mathrm{C}$ or more, after which point permeability increased dramatically (over two orders of magnitude), then continued to increase with temperature at a reduced rate (Fig. $5 \mathrm{~d}$ ).

\section{Evolution of physical and mechanical properties with acid immersion}

Data for the suite of samples subject to acid immersion are given in Table 2 and Fig. 6. Normalised data of any given property $a$ is shown as $\bar{a}$, such that $\bar{a}$ is $a$ relative to the pre-immersion value. For compressive strength, experimental data are normalised to the range of values obtained in the untreated sample suite (Table 2). The samples from the altered granite suite G2M-B (B1, B3, B6, B7, B12-15, see Table 2) were immersed in a 2.0 


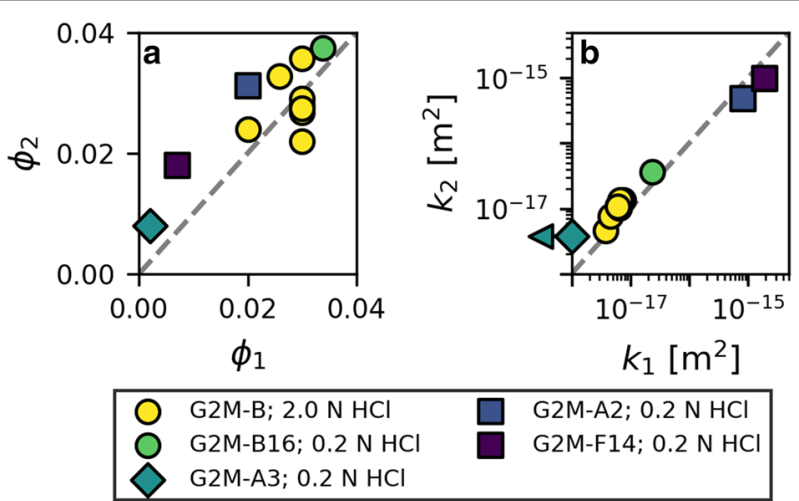

Fig. 7 Pre- and post-immersion measurements. a Porosity $(\phi)$. b Permeability ( $k$ ). Subscripts 1 and ${ }_{2}$ denote initial and post-immersion data, respectively

$\mathrm{M}$ solution of $\mathrm{HCl}$ for varying lengths of time. Sample mass decreases monotonically as a function of total immersion time, from a minimum of 24 hours (1 day) up to a maximum of $1008 \mathrm{~h}$ (42 days), with the normalised mass $\bar{m}$ decreasing by approximately $1 \%$ (Fig. 6a). This progressive mass loss is not reflected in a consistent increase in porosity (Fig. 6b), but permeability was always higher in these samples after immersion (Fig. 6c). Uniaxial compressive strength, shown in Fig. $6 \mathrm{~d}$ generally appears to increase relative to the sample suite that was not subject to acid treatment (see Table 2), but this trend is not echoed by the Young's modulus data (Table 2). The remaining samples were left in a $0.2-\mathrm{M} \mathrm{HCl}$ solution for $1008 \mathrm{~h}$. The altered granite sample (G2M-B16: Table 2) exhibited much the same patterns of mass decrease, permeability increase, and negligible porosity change observed in the altered suite in more concentrated acid, although to a lesser degree. All other samples (G2M-A3, G2M-A2, and G2M-F14: an unaltered granite, a thermally fractured granite, and a naturally fractured granite, respectively), exhibited slight mass loss (Fig. 6a), and a moderate increase in relative porosity (Fig. 6b). This latter behaviour is more pronounced in the unaltered granite, which contained the lowest initial porosity. In terms of permeability, the unaltered sample A3 underwent an increase from being essentially impermeable (on the order of $10^{-21} \mathrm{~m}^{2}$ ) to around $4 \times 10^{-18} \mathrm{~m}^{2}$ : an increase of around three orders of magnitude. On the other hand, the fractured granites both underwent a decrease in permeability after acid immersion.

A comparison of initial and post-immersion porosity and permeability are shown in Fig. 7. As shown in Fig. 6, post-immersion porosity is generally higher than the initial porosity, with the maximum real increase seen in the naturally and thermally fractured samples (with initial porosities of 0.007 and 0.023 , respectively). The altered suite immersed in 2.0-M HCl solution exhibits scatter on both sides of the $\phi_{1}=\phi_{2}$ dashed line, while many samples that plot above this line (i.e. porosity increase) tend to be those samples that underwent immersion for the longest time (see Table 2); this trend is not systematic. Figure $7 \mathrm{~b}$ shows pre- and post-immersion permeability data $\left(k_{1}\right.$ and $\left.k_{2}\right)$. The unaltered and unfractured granite sample shows a significant increase above $k_{1}=k_{2}$ while the altered suite plots close to the line, both for the 2.0 and $0.2 \mathrm{M}$ acid solutions. However, the fractured samples (initially the most permeable samples), plot below the line, highlighting that their permeability decreased in real terms. 


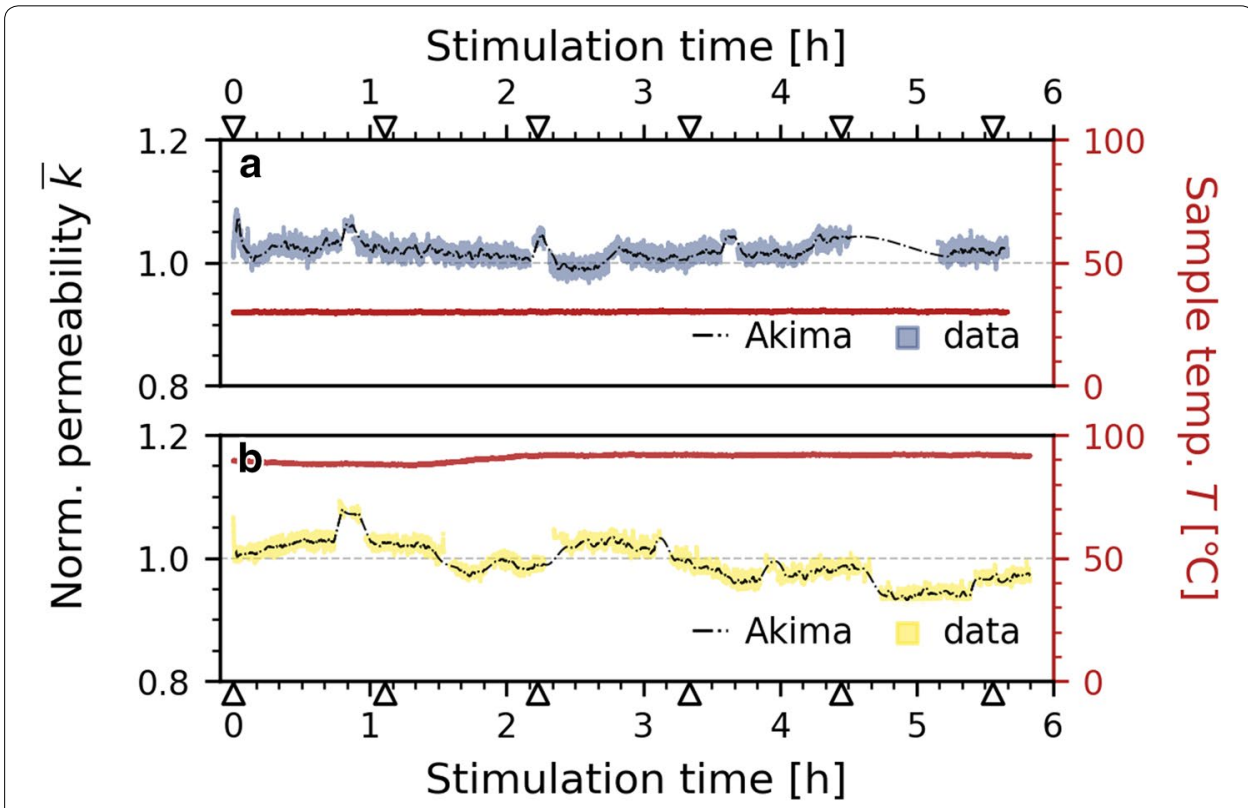

Fig. 8 Evolution of sample permeability during acid flow-through experiments. a Sample G2M-A5, subject to approximately $6 \mathrm{~h}$ of stimulation with $0.2-\mathrm{M} \mathrm{HCl}$ solution, at a sample temperature of $30^{\circ} \mathrm{C}$. Triangles indicate times whereat aliquots of effluent acid solution were sampled for further analysis. Normalised data are shown in colour, and dash-dot line is an Akima spline function used to interpolate missing data. b Sample $\mathrm{G} 2 \mathrm{M}-\mathrm{A} 6$, subject to approximately $6 \mathrm{~h}$ of stimulation with $0.2-\mathrm{M} \mathrm{HCl}$ solution, at a sample temperature of $100^{\circ} \mathrm{C}$. Triangles indicate times whereat aliquots of effluent acid solution were sampled for further analysis. Normalised data are shown in colour, and dash-dot line is an Akima spline function used to interpolate missing data. Note that only the acid flow-through portion of the experiments are shown: the pre- and post-stimulation stages using deionised $\mathrm{H}_{2} \mathrm{O}$ are omitted for clarity

\section{Evolution of permeability during acid stimulation}

Permeability data obtained during acid stimulation experiments are shown in Fig. 8, calibrated for pressure and temperature variation according to Eq. 6 and Farquharson et al. (2017b), and normalised to the initial sample permeability. In both cases, only slight and non-systematic variations in sample permeability are observed throughout the stimulation phase (around $6 \mathrm{~h}$ ). Given that the initial permeabilities are on the order of $10^{-21} \mathrm{~m}^{2}$, maximum relative permeability changes of \pm 0.1 only correspond to permeability variations on the order of $10^{-22} \mathrm{~m}^{2}$.

\section{Evolution of acid chemistry during acid stimulation}

ICP-AES data are shown in Fig. 9 for selected elements. Ca (Fig. 9a), Na (Fig. 9b), and Mg (Fig. 9c) all exhibit similar trends at both high and low temperatures, characterised by a peak after approximately 1 hour (4000 s) followed by an asymptotic decrease in elemental concentration in the acid solution over time. Concentrations are generally marginally higher for the high-temperature data, and Ca appears in much higher concentrations relative to $\mathrm{Na}$ or $\mathrm{Mg}$ (as much as $35.5 \mathrm{ppm}$, compared to $\sim 7 \mathrm{ppm}$ ). The room-temperature data for $\mathrm{Si}$ follows a similar pattern (Fig. 9d); however, after the initial sharp increase, Si concentration in effluent from the high-temperature experiment continues to increase, albeit at a reduced rate. $\mathrm{Al}$ (Fig. 9e) remained below detectable limits until over $2 \mathrm{~h}$ of stimulation $(8000 \mathrm{~s})$, then 

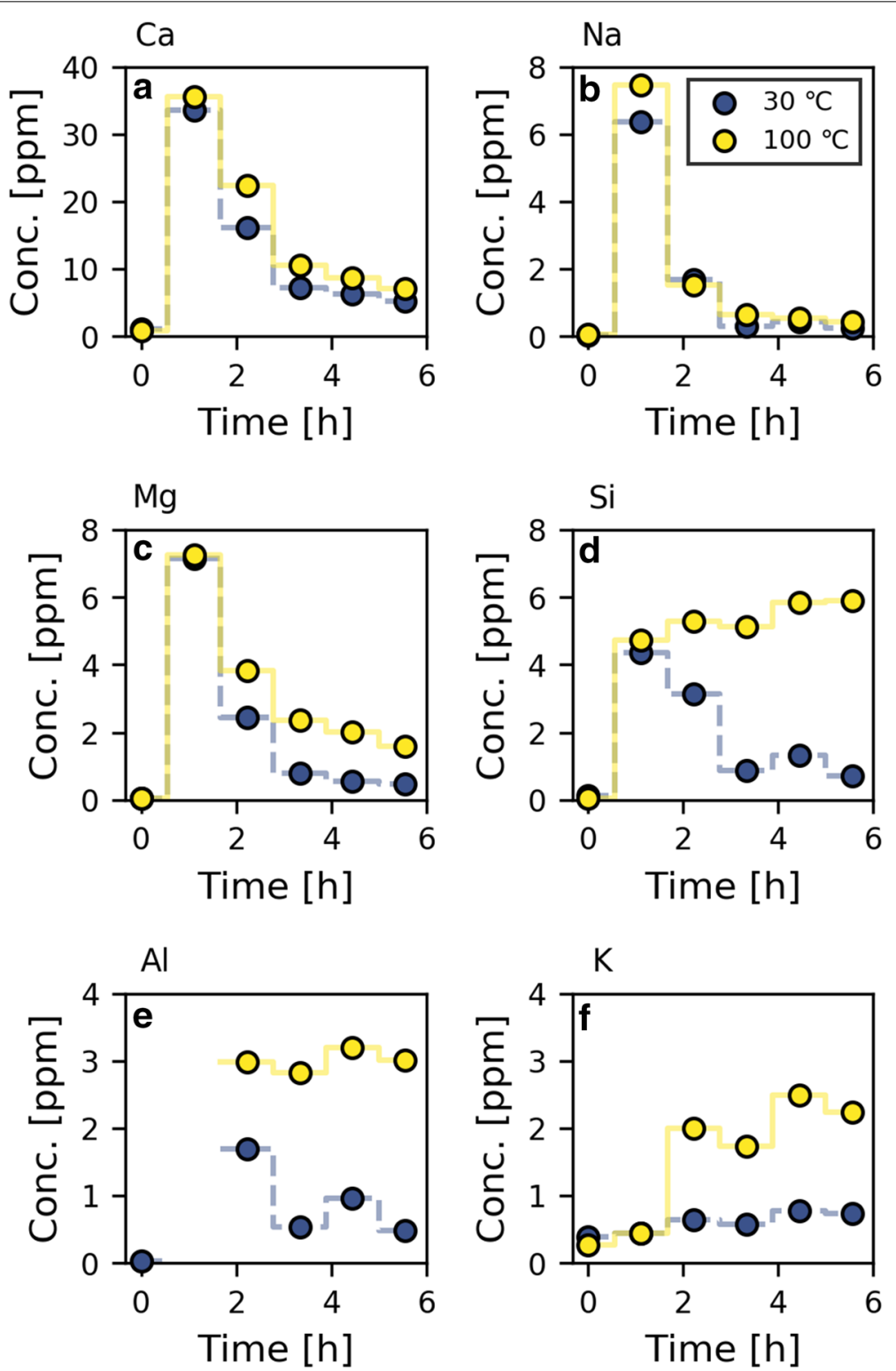

Fig. 9 Inductively coupled plasma atomic emission spectroscopy (ICP-AES) data. a Calcium, b sodium, c magnesium, $\mathbf{d}$ silicon, e aluminium, and $\mathbf{f}$ potassium. Dark blue symbols refer to data collected during the room-temperature $\left(30^{\circ} \mathrm{C}\right.$ ) experiment (Fig. 8); light-coloured (yellow) symbols refer to data collected during the high-temperature $\left(100^{\circ} \mathrm{C}\right)$ experiment (Fig. 8). All concentrations are shown in parts per million (ppm)

followed a similar trend to $\mathrm{Si}$ (Fig. 9d): an apparent steady decrease in $\mathrm{Al}$ during the room-temperature stimulation (from 1.7 to $0.5 \mathrm{ppm}$ ), and a higher concentration at a relatively steady rate during the high-temperature stimulation (between 3.0 and $3.2 \mathrm{ppm}$ ). Finally, $\mathrm{K}$ shows a slow and steady increase over time in the roomtemperature data (to a maximum of $0.7 \mathrm{ppm}$ : Fig. 9f). During the high-temperature stimulation, $\mathrm{K}$ follows the same trend as for the room-temperature data until around $3 \mathrm{~h}$ and $20 \mathrm{~min}(12000 \mathrm{~s})$ into the stimulation, after which it deviates from the roomtemperature trend, appearing in higher concentrations ( $\sim 2 \mathrm{ppm})$. 


\section{Discussion}

\section{Thermal stress treatment}

We performed thermal stress experiments on selected samples of two-mica granite simply as part of initial sample characterisation; nevertheless, the tests reveal some interesting results (Fig. 5). Data from these pilot thermal treatment experiments show that subjecting these granites to temperatures above $\sim 200^{\circ} \mathrm{C}$ appears to be an extremely effective mechanism by which to increase permeability (three to six orders of magnitude greater than the initial material). We infer the increase of sample porosity and volume, and the concomitant decrease in P-wave velocity, to reflect the generation of microfractures during heating: the result of cumulative mechanical stresses, in turn a function of the mismatch in thermal expansion of the constituent crystals (e.g. Fredrich and Wong 1986). We highlight that in a previous study on thermal cracking of granite, Griffiths et al. (2018) observed that a P-wave velocity decrease recorded in situ during heating was irreversible: this suggests that the physical properties of our thermally cracked granites-although not measured during the heating cycle-still reflect the same processes as in situ measurements. Notably, permeability increases only after a temperature of approximately $200^{\circ} \mathrm{C}$, a threshold which we interpret as the coalescence of diffuse disparate fractures into a through-running, connected fracture network (Meredith et al. 2012). After this point, it appears possible to continue increasing permeability with heating and cooling cycles to iteratively higher target temperatures. Whether this could prove to be an effective technique for stimulation at the reservoir scale is unknown, although we highlight that such a strategy would likely not be seismically quiet. For example, Griffiths et al. (2018) observed that thermally induced crack initiation and propagation in low-porosity granite was associated with acoustic emissions: a laboratory-scale proxy for seismicity. Moreover, the sustainability of such an approach is questionable due to the Kaiser "stress-memory" effect: a phenomenon whereby new fractures may be generated only after the stress level of any previous stress events has been exceeded (e.g. Kaiser 1953; Lavrov 2003). Nevertheless, thermal treatments have been shown to prove an effective means of reservoir enhancement in some cases (e.g. the Bouillante geothermal site, Guadeloupe Correia et al. 2000; Tulinius et al. 2000). Further experimental work in this arena may yet prove fruitful.

\section{Response of granites to acid immersion}

The altered granite suite G2M-B (B1, B3, B6, B7, B12-15) proved most susceptible to dissolution during the batch immersion tests, evidenced by the degree of mass loss (Fig. 6a) relative to the other granite samples. However, the difference between the altered samples immersed in $0.2-$ and $2.0-\mathrm{M} \mathrm{HCl}$ solution is minor in terms of mass loss, and negligible in terms of porosity and permeability increase (Fig. 6b, c), despite the acid concentration being an order of magnitude greater in the latter case. This suggests that any ongoing dissolution processes during these tests are either limited by the availability of soluble material within the samples rather than the acid concentration recorded in the bulk fluid.

While the unaltered unfractured granite (G2M-A3) exhibited the greatest relative change in permeability as a result of acid immersion (three orders of magnitude or more: 
Fig. 6b), the sample ultimately never became as permeable as the altered or fractured material in their as-collected state (Table 2, Fig. 7a). Interestingly, the most permeable samples-those containing natural or thermally induced fractures-became less permeable after acid immersion. While geochemical data are not available for these experiments, this suggests that precipitation rather than dissolution mechanisms become dominant in high-permeability materials, or that pre-existing fluid-flow pathways became otherwise clogged with material. While have a large element release from the sample into solution which could be prone to precipitate under favourable thermodynamic conditions, we highlight that these are relatively unlikely in the $\mathrm{pH}$ range investigated here $\sim[-0.3,+0.7]$. Unfortunately, our approach does not allow us to access to the local fluid saturation in the confined pore environment, which may differ from the bulk.

Curiously, the samples for which compressive strength testing was carried out (see Fig. 6d) exhibited an increase in UCS relative to the untreated sample suite. Typically, an increase in porosity (Fig. 6b) would be expected to systematically decrease strength. It is possible that any operative dissolution mechanisms actually serve to preferentially increase pore sphericity, in turn influencing the micromechanical behaviour of the granite samples as a whole. In such low-porosity granites, it may be that the pore shape is as important, if not more so, than the absolute void fraction. Alternatively, progressive removal of clay minerals over time may counteract the general weakening effect often observed in clay-bearing granites (e.g. Dearman et al. 1978; Lumb 1983). However, further detailed study is required in order to explain this phenomenon. Young's moduli of the different sample suites do not appear to vary systematically: the mean modulus values of the treated and non-treated suites are 20.87 and $21.41 \mathrm{GPa}$, respectively, with corresponding standard deviations of 3.33 and $2.71 \mathrm{GPa}$, indicating that there is not a significant change in material stiffness.

\section{Dissolution mechanisms}

Given the experimental conditions involved herein, it is expected that any dissolution process is characterised by element release into solution (Takaya 2014). Generally, this is what we observe: ICP-AES data (Fig. 9) indicates an increase in concentration of all elements tracked, both during the room-temperature and high-temperature experiments. $\mathrm{Ca}, \mathrm{Na}$, and $\mathrm{Mg}$ presumably derived from the apatite $\left(\mathrm{Ca}_{10}\left(\mathrm{PO}_{4}\right)_{6}(\mathrm{OH}, \mathrm{F}, \mathrm{Cl})_{2}\right)$, albite $\left(\mathrm{NaAlSi}_{3} \mathrm{O}_{8}\right)$, and biotite $\left(\mathrm{K}(\mathrm{Mg}, \mathrm{Fe})_{3} \mathrm{AlSi}_{3} \mathrm{O}_{10}(\mathrm{~F}, \mathrm{OH})\right)$ identified in our samples, although it is possible that minerals such as calcite-previously identified in Soultzsous-Forêts basement rock (e.g. Ledésert et al. 1996; Hébert et al. 2010; Ledésert et al. 2010) - are also present in low abundance and contribute to the recorded pattern of element evolution in the acid solution. Thermodynamic calculations based on concentrations measured by ICP-AES (or concentrations assumed stoichiometric for other elements not measured) yielded saturation indices $<0$ for all of these minerals (barring quartz) under all tested conditions.

Over the course of the acid flow-through experiments, these elements $(\mathrm{Ca}, \mathrm{Na}, \mathrm{Mg})$ are flushed out quickly, and continue to be removed from the granite at a rate that asymptotically decreases towards zero with time. The decreasing rate of cation removal suggests that the process is limited by the availability of these reactive minerals, which is in agreement with their generally low abundance in the unaltered granite. Although 
there appears to be some dependence on temperature (e.g. Nelson et al. 1989; Zafar et al. 2006) the difference between cation release rate at low and high temperature is small. The pattern of cation concentration evolution for $\mathrm{Si}, \mathrm{Al}$, and $\mathrm{K}$ tell a different story. We interpret the coincident evolution of these cations to reflect the dissolution of silicate minerals; in particular K-feldspar (orthoclase and microcline), but also perhaps muscovite and illite, which appear in lesser abundance in the initial material. The dissolution of feldspar exhibits a pronounced dependence on temperature, as demonstrated by previous experimental studies (e.g. Chen and Brantley 1997; Hellmann 1995). The observed differences in temperature-dependence are generally consistent with $\mathrm{KAlSi}_{3} \mathrm{O}_{8}$ stoichiometry: K-feldspar has an activation energy of about $52 \mathrm{~kJ} \mathrm{~mol}^{-1}$, so in theory it should dissolve about 50 times faster at $100^{\circ} \mathrm{C}$ than at $30^{\circ} \mathrm{C}$. Biotite should dissolve about 10 times slower, and is more scarce, which makes the $\mathrm{Mg}$ concentration low and its contribution to the other element budgets $(\mathrm{K}, \mathrm{Al}, \mathrm{Si})$ nearly negligible. For elements such as $\mathrm{Ca}$, the recorded behaviour is consistent with the dissolution being limited by the reactive surface area of Ca-bearing minerals (e.g. apatite) accessible to the fluid, but further targeted experiments are required to fully elucidate these processes.

\section{Viability of chemical stimulation for enhancing the Soultz-sous-Forêts reservoir}

Results of previous $\mathrm{HCl}$ stimulation of the Soultz-sous-Forêts wells have been mixed. The GPK-2 well was stimulated with a solution of $\mathrm{HCl}$ in 2002, yielding no clear improvement in the productivity of the formation (Portier et al. 2009). The following year, a stimulation campaign was carried out in the GPK-3 well using $\mathrm{HCl}$ and organic clay acid, with no evidence of productivity increase. The GPK-4 well was stimulated in 2005 using $\mathrm{HCl}$, an approach which nominally increased the productivity index of the well (Portier et al. 2009). However, it remains unclear as to whether this was due to chemical stimulation in the openhole portion (the desired outcome). Rather, temperature anomalies and a nucleation of seismic events strongly suggest that productivity was "enhanced" due to a leak in the cemented casing, several hundred meters above the openhole section of the well. Moreover, hydraulic communication between the GPK wells decreased following stimulation (Nami et al. 2008). This demonstrates some of the complexity involved in the chemical stimulation process: although in the near-field dissolution mechanisms may increase permeability - and hence, productivity - of the granite reservoir (Portier and Vuataz 2010), it is feasible that precipitation-induced occlusion of fluid pathways could serve to decrease the overall productivity of the reservoir. Attempted stimulation of GPK-4 using other chemical agents (such as chelants) have thus far proven to be ineffectual, actually decreasing the productivity of the formation (Portier et al. 2009).

Our immersion tests show that permeability decreased over time for the most permeable samples (Fig. 7), perhaps due to precipitation or occlusion, as found in previous experimental work (e.g. Thomas et al. 2001). If, as assumed by Ngo et al. (2016), introduced fluids are primarily in contact with the fractured and altered material, a new stimulation campaign employing $\mathrm{HCl}$ will most likely encounter similar issues to those described in previous pilot studies (Portier et al. 2009); namely, that any effect on well productivity will be negligible or detrimental.

The ratio of acid to granite in the batch reaction experiments (see Fig. 3) is extremely high, and these experiments therefore probably provide an overestimate of the 
effectiveness of a real-world acid stimulation campaign: achieving such a ratio during downhole stimulation would not be operationally feasible. The laboratory flow-through experiments using the acid-permeametry apparatus (Figs. 4, 8), on the other hand, should better represent the rates of dissolution or precipitation at the industrial scale. Clearly, however, the amount of permeability change in the unaltered granite is negligible, both at room temperature and at $100{ }^{\circ} \mathrm{C}$ (Fig. 8). As highlighted above, the amount of permeability gained or lost by the sample throughout the 6-h stimulation process is on the order of $10-22 \mathrm{~m}^{2}$, showing that a solution of $\mathrm{HCl}$ proves ineffective at enhancing the permeability of materials nominally representative of the granitic basement at Soultz-sous-Forêts, even at elevated temperature. While downhole temperatures at Soultz-sous-Forêts are higher still (upwards of $150^{\circ} \mathrm{C}$, e.g. Pribnow et al. 2000), we note that confining pressure will also be higher at depth in the reservoir, a factor that inhibits permeability in granite (e.g. Brace et al. 1968; Bernabe 1986; Kranz et al. 1979). Our experimental data echo the results of Lucas et al. (2019), who model a series of chemical stimulation scenarios at Soultz-sous-Forêts. They find that any potential improvement of reservoir productivity is restricted to a small zone (a matter of metres) close to the injection point, with dissolution-induced permeability enhancement being tempered by hydrothermal mineral precipitation. In that study, permeability enhancement was primarily driven by dissolution of Ca-rich feldspars, which are found in relatively low abundance throughout the Soultz-sous-Forêts reservoirs (e.g. Meller and Ledésert (2017)). In contrast, the $\mathrm{Na}-\mathrm{K}$ members such as microcline and albite generally appear in greater abundance, but are significantly harder to break down using $\mathrm{HCl}$ (e.g. Palandri and Kharaka 2004), even under similar experimental conditions (e.g. Casey et al. 1991; Stillings and Brantley 1995). In short, this suggests that the potential for chemical stimulation of the Soultz-sous-Forêts site is limited without turning to more complex stimulating fluids.

\section{Conclusions}

As part of the DESTRESS Horizon-2020 framework, the GPK-4 well at Soultz-sousForêts is being targeted for chemical stimulation. Using a combination of batch reaction tests and a new, custom-built high-temperature acid permeameter, we explore the potential for porosity and permeability increase in a two-mica granite, analogous to that at depth in the Soultz-sous-Forêts basement. We characterise three sample suites: an unaltered granite, an altered granite, and a fractured granite. Porosity ranges from $<0.1$ to 3.4 vol.\% in the as-collected samples, with permeability varying on the order $10^{-21}$ to $10^{-15} \mathrm{~m}^{2}$ depending on the degree of alteration and the abundance of fractures. Altered granites proved to be relatively susceptible to dissolution during batch reaction tests, reflected in a loss of sample mass and a general increase in porosity and permeability over time. We note only a slight increase in total mass loss (i.e. dissolution), absolute porosity change, and permeability increase when we compare similar samples subjected to $\mathrm{HCl}$ at a higher molarity (2.0 as opposed to $0.2 \mathrm{M}$ ). Sample strength appears to increase slightly with continued acid immersion, potentially due to an alteration of pore shape, the progressive removal of relatively weak clay minerals, or a combination of both. This mechanical phenomenon is not reflected in a significant change in Young's modulus. 
We observe that thermal treatment of Soultz-sous-Forêts granite above $200-300^{\circ} \mathrm{C}$ is clearly a highly effective method by which to induce new fractures and increase permeability, in some cases by up to six orders of magnitude. While it is not the focus of this contribution, we suggest that the operational feasibility of a thermal stimulation campaign (taking into account commercial sustainability and the potential for induced seismicity) warrants further study. Both thermally and naturally fractured granites-initially the most permeable samples-exhibited a decrease in permeability as a result of acid immersion, either due to mineral precipitation or clogging of preexisting fluid pathways in the granites.

While we do demonstrate that permeability can be initiated in formerly impermeable unaltered granite via acid stimulation, the ratio of acid to rock required likely renders this specific approach impossible to deploy in a real-world scenario. When we stimulate granite from the same sample suite using an acid flow-through system, time-resolved data from inductively coupled plasma atomic emission spectroscopy (ICP-AES) of the effluent fluid highlights the fact that dissolution does indeed occur. ICP-AES data reveal an increase in $\mathrm{Ca}, \mathrm{Na}$, and $\mathrm{Mg}$ abundance in the effluent fluid during flow-through tests, suggesting dissolution of apatite, albite, and biotite in these granites (as well as any other soluble minerals that may be present but undetected in our samples). These relatively reactive elements are initially removed rapidly from the granite, at a rate that decreases asymptotically over time. Over the range of temperatures tested $\left(30-100^{\circ} \mathrm{C}\right)$, the temperature-dependence of the attendant dissolution processes is generally low. The pattern of evolution of $\mathrm{Si}, \mathrm{Al}$, and $\mathrm{K}$, however, exhibits a more pronounced dependence on temperature, and is inferred to result from the dissolution of silicate minerals: K-feldspar (orthoclase and microcline), muscovite, and illite. This evolution results from a complex interplay between the dissolution of granite-forming minerals and the in situ precipitation of secondary phases. Despite clear evidence for mineral dissolution, however, the recorded permeability change over a period of $6 \mathrm{~h}$ is not significant.

Ultimately, the potential for permeability enhancement at Soultz-sous-Forêts using $\mathrm{HCl}$ alone is low, a finding that is in agreement with recent geochemical modelling data. We find that the permeability increase in the least permeable granites is almost negligible when acid is flushed through these samples, despite promising results in initial batch reaction experiments. On the other hand, it appears that $\mathrm{HCl}$ can act to decrease the permeability of the more permeable reservoir constituents: altered and fractured granites. The Soultz-sous-Forêts granite exhibits a general lack of Ca-rich feldspars, which are much more easily broken down by $\mathrm{HCl}$ than $\mathrm{Na}-\mathrm{K}$ members (e.g. microcline and albite) under similar experimental conditions. It is questionable, therefore, whether a higher molarity $\mathrm{HCl}$ stimulation would prove more effective in the long-term. Nevertheless, effective chemical stimulation of the reservoir using alternative acidic agents cannot be discounted: chemical data collected during our experiments illuminate a number of dissolution mechanisms operative throughout. If these reactions could be targeted and promoted using organic or mineral acids, or a combination thereof, then acid enhancement of the Soultz-sous-Forêts reservoir may yet bear fruit. Critically, we recommend that a thorough experimental campaign should be used to inform any future stimulation campaigns. 


\section{Acknowledgements}

We thank three anonymous reviewers, whose comments helped improve the manuscript. Additional thanks go to Arjun Kohli, Alex Schubnel, Thierry Reuschlé, Mike Heap, and many others for pertinent discussions, Bertrand Renaudié for sample preparation, Scott Vermeer (from Chandler Engineering) and Laurent Rihouey for technical assistance, and Andrea Caciolo for administrative assistance. This work would not have been possible without the information and advice provided by numerous industrial fabricators and manufacturing companies, including (but not limited to) those from dp Seals, HTS/AmpTek, and Temperatur Messelemente Hettstedt GmbH. In addition, productive meetings with researchers and industrial partners within the DESTRESS consortium, in particular those in adjacent working groups, were invaluable in shaping the research design.

\section{Authors' contributions}

JF designed and built the experimental equipment, and performed the acid dissolution experiments. AK collected the sample material, performed much of the sample characterisation, and facilitated the ICP-AES analyses. BW performed the SEM analysis. PB collected the sample materials and managed the project. All authors contributed to the writing of the manuscript. All authors read and approved the final manuscript.

\section{Funding}

We are grateful for the financial support of the DESTRESS European research programme. This project has received funding from the European Union's Horizon 2020 research and innovation programme under Grant Agreement No. 691728.

\section{Data availability}

Part of the experimental data are provided in tables in the manuscript. All other data can be made available on reasonable request to the author(s).

\section{Competing interests}

The authors declare no competing interests.

\section{Author details}

${ }^{1}$ Rosenstiel School of Marine and Atmospheric Sciences, University of Miami, 4600 Rickenbacker Causeway, Miami, FL 33149, USA. ${ }^{2}$ Géophysique Expérimentale, Institut de Physique de Globe de Strasbourg (UMR 7516 CNRS), Université de Strasbourg/EOST, 5 rue René Descartes, 67084 Strasbourg, France. ${ }^{3}$ Andlinger Center for Energy and the Environment, Princeton University, Princeton, NJ, USA.

Received: 22 November 2019 Accepted: 17 April 2020

Published online: 29 April 2020

\section{References}

Aichholzer C, Duringer P, Orciani S, Genter A. New stratigraphic interpretation of the soultz-sous-forêts 30-year-old geothermal wells calibrated on the recent one from rittershoffen (upper rhine graben, france). Geothermal Energy. 2016;4(1):13.

Aquilina L, Pauwels H, Genter A, Fouillac C. Water-rock interaction processes in the triassic sandstone and the granitic basement of the rhine graben: geochemical investigation of a geothermal reservoir. Geochim Cosmochim Acta. 1997;61 (20):4281-95.

Bächler D, Kohl T, Rybach L. Impact of graben-parallel faults on hydrothermal convection—rhine graben case study. Phys Chem Earth Parts A/B/C. 2003;28(9):431-41.

Bernabe $Y$. The effective pressure law for permeability in chelmsford granite and barre granite. In: International Journal of Rock Mechanics and Mining Sciences \& Geomechanics Abstracts; 1986. vol. 23, Amsterdam: Elsevier; p. 267-275.

Brace W, Walsh J, Frangos W. Permeability of granite under high pressure. J Geophys Res. 1968;73(6):2225-36.

Casey WH, Westrich HR, Holdren GR. Dissolution rates of plagioclase at pH=2 and 3. Am Mineral. 1991;76(1-2):211-7.

Chen Y, Brantley SL. Temperature-and pH-dependence of albite dissolution rate at acid ph. Chem Geol. 1997;135(3-4):275-90

Cocherie A, Guerrot C, Fanning CM, Genter A. Datation u-pb des deux faciès du granite de soultz (fossé rhénan, France). Comptes Rendus Geosci. 2004;336(9):775-87.

Correia H, Sigurdsson O, Sanjuan B, Tulinius H, Lasne E. Stimulation of a high-enthalpy geothermal well by cold water injection. Transactions-Geothermal Resources Council. 2000. p. 129-36.

Dearman W, Baynes F, Irfan T. Engineering grading of weathered granite. Eng Geol. 1978;12:345-74.

Dezayes C, Villemin T, Genter A, Traineau H, Angelier J. Analysis of fractures in boreholes of hot dry rock project at soultzsous-forêts (Rhine Graben, France). J Sci Drill. 1995;5(1):31-41.

Dezayes C, Valley B, Maqua E, Syren G, Genter A. Natural fracture system of the soultz granite based on ubi data in the gpk3 and gpk4 wells. In: Proceedings of the EHDRA scientific conference; 2005. p. 9. Soultz-sous-Forêts France

Dezayes C, Genter A, Valley B. Structure of the low permeable naturally fractured geothermal reservoir at soultz. Comptes Rendus Geosci. 2010;342(7):517-30.

Duchane D, Brown D. Hot dry rock (HDR) geothermal energy research and development at Fenton Hill, New Mexico. Geo-Heat Centre Q Bull. 2002;23(4):13-9.

Farquharson JI, Heap MJ, Lavallée Y, Varley NR, Baud P. Evidence for the development of permeability anisotropy in lava domes and volcanic conduits. J Volcanol Geotherm Res. 2016:323:163-85.

Farquharson Jl, Baud P, Heap MJ. Inelastic compaction and permeability evolution in volcanic rock. Solid Earth. 2017a;8(2):561.

Farquharson JI, Wadsworth FB, Heap MJ, Baud P. Time-dependent permeability evolution in compacting volcanic fracture systems and implications for gas overpressure. J Volcanol Geotherm Res. 2017b;339:81-97. 
Flores M, Davies D, Couples G, Palsson B. Stimulation of geothermal wells, can we afford it. In: Proceedings world geothermal congress; 2005. p. 1.

Fredrich JT, Wong T-f. Micromechanics of thermally induced cracking in three crustal rocks. J Geophys Res Solid Earth. 1986;91(B12):12743-64.

Freymark J, Sippel J, Scheck-Wenderoth M, Bär K, Stiller M, Fritsche J-G, Kracht M. The deep thermal field of the upper rhine graben. Tectonophysics. 2017;694:114-29.

Fridleifsson IB. Geothermal energy for the benefit of the people. Renew Sustain Energy Rev. 2001;5(3):299-312.

Fridleifsson IB, Bertani R, Huenges E, Lund JW, Ragnarsson A, Rybach L, et al. The possible role and contribution of geothermal energy to the mitigation of climate change. In: IPCC scoping meeting on renewable energy sources proceedings. Luebeck, Germany; 2008. vol. 20, p. 59-80. Citeseer.

Genter A, Evans K, Cuenot N, Fritsch D, Sanjuan B. Contribution of the exploration of deep crystalline fractured reservoir of soultz to the knowledge of enhanced geothermal systems (egs). Comptes Rendus Geosci. 2010;342(7):502-16.

Genter A, Cuenot N, Melchert B, Moeckes W, Ravier G, Sanjuan B, Sanjuan R, Scheiber J, Schill E, Schmittbuhl J. Main achievements from the multi-well egs soultz project during geothermal exploitation from 2010 and 2012. In: European geothermal congress 2013; 2013. p. 10

Gérard A, Genter A, Kohl T, Lutz P, Rose P, Rummel F. The deep EGS (enhanced geothermal system) project at Soultz-sousForêts (Alsace, France). Geothermics. 2006;35:473-83.

Griffiths L, Lengliné O, Heap M, Baud P, Schmittbuhl J. Thermal cracking in westerly granite monitored using direct wave velocity, coda wave interferometry, and acoustic emissions. J Geophys Res Solid Earth. 2018;123(3):2246-61.

Heap MJ, Wadsworth FB. Closing an open system: pore pressure changes in permeable edifice rock at high strain rates. J Volcanol Geotherm Res. 2016;315:40-50.

Heap M, Lavallée Y, Petrakova L, Baud P, Reuschle T, Varley N, Dingwell DB. Microstructural controls on the physical and mechanical properties of edifice-forming andesites at volcán de colima, mexico. J Geophysi Res Solid Earth. 2014;119(4):2925-63.

Heap MJ, Kushnir AR, Gilg HA, Wadsworth FB, Reuschlé T, Baud P. Microstructural and petrophysical properties of the permo-triassic sandstones (buntsandstein) from the soultz-sous-forêts geothermal site (france). Geotherm Energy. 2017;5(1):26.

Heap MJ, Kushnir AR, Gilg HA, Violay ME, Harlé P, Baud P. Petrophysical properties of the muschelkalk from the soultzsous-forêts geothermal site (france), an important lithostratigraphic unit for geothermal exploitation in the upper rhine graben. Geothermal Energy. 2019;7(1):27.

Hébert RL, Ledésert B, Bartier D, Dezayes C, Genter A, Grall C. The enhanced geothermal system of soultz-sousforêts: a study of the relationships between fracture zones and calcite content. Jo Volcanol Geothermal Res. 2010;196(1-2):126-33.

Hellmann R. The albite-water system: Part II. The time-evolution of the stoichiometry of dissolution as a function of pH at 100, 200, and 300 c. Geochim Cosmochim Acta. 1995;59(9):1669-97.

IAPWS: Release on the iapws formulation 2008 for the viscosity of ordinary water substance. IAWPS meeting September 2008. Technical report, Berlin, Germany; 2008.

Kaiser J. Erkenntnisse und folgerungen aus der messung von geräuschen bei zugbeanspruchung von metallischen werkstoffen. Archiv für das Eisenhüttenwesen. 1953;24(1-2):43-5.

KamLAND Collaboration. Partial radiogenic heat model for earth revealed by geoneutrino measurements. Nat Neurosci. 2011;4(9):647-51.

Klinkenberg L, et al. The permeability of porous media to liquids and gases. In: Drilling and Production Practice; 1941. American Petroleum Institute

Kranz R, Frankel A, Engelder T, Scholz C. The permeability of whole and jointed barre granite. In: International Journal of Rock Mechanics and Mining Sciences \& Geomechanics Abstracts; 1979. vol. 16, Amsterdam: Elsevier; p. 225-34.

Kushnir ARL, Martel C, Champallier R, Wadsworth F. Permeability evolution in variably glassy basaltic andesites measured under magmatic conditions. Geophys Res Lett. 2017;44(20).

Kushnir AR, Heap MJ, Baud P. Assessing the role of fractures on the permeability of the permo-triassic sandstones at the soultz-sous-forêts (france) geothermal site. Geothermics. 2018;74:181-9.

Lavrov A. The kaiser effect in rocks: principles and stress estimation techniques. Int J Rock Mech Mining Sci. 2003:40(2):151-71.

Ledésert B, Joffre J, Amblès A, Sardini P, Genter A, Meunier A. Organic matter in the soultz hdr granitic thermal exchanger (france): natural tracer of fluid circulations between the basement and its sedimentary cover. J Volcanol Geothermal Res. 1996;70(3-4):235-53.

Ledésert B, Hebert R, Genter A, Bartier D, Clauer N, Grall C. Fractures, hydrothermal alterations and permeability in the soultz enhanced geothermal system. Comptes Rendus Geosci. 2010;342(7-8):607-15.

Lucas Y, Ngo WV, Clément A, Fritz B, Schäfer G. Modelling acid stimulation in the enhanced geothermal system of soultzsous-forêts (Alsace, France). Geothermics. 2019;85(101772):1-13. https://doi.org/10.1016/j.geothermics.2019.10177 2.

Lumb P. Engineering properties of fresh and decomposed igneous rocks from hong kong. Eng Geol. 1983;19(2):81-94.

McPhee CA, Arthur KG. Klinkenberg permeability measurements: problems and practical solutions. In: Advances in core evaluation IL reservoir appraisal, Proceedings of the 2 nd society of core analysts European core analysis symposium, Gordon \& Breach Science Publishers, Philadelphia; 1991. p. 371-91.

Meller C, Ledésert B. Is there a link between mineralogy, petrophysics, and the hydraulic and seismic behaviors of the soultz-sous-forêts granite during stimulation? a review and reinterpretation of petro-hydromechanical data toward a better understanding of induced seismicity and fluid flow. J Geophys Res Solid Earth. 2017;122(12):9755-74.

Meredith P, Main I, Clint O, Li L. On the threshold of flow in a tight natural rock. Geophys Res Lett. 2012;39(4).

Morrow C, Moore DE, Lockner D. Permeability reduction in granite under hydrothermal conditions. J Geophys Res Solid Earth. 2001;106(B12):30551-60. 
Nami P, Schellschmidt R, Schindler M, Tischner T. Chemical stimulation operations for reservoir development of the deep crystalline hdr/egs system at soultz-sous-forêts (france). In: Proceedings, 32nd workshop on geothermal reservoir engineering, Stanford University, Stanford, California, USA; 2008. p. 28-30

Nelson D, Barry J, Shields C, Glena R, Featherstone J. Crystal morphology, composition, and dissolution behavior of carbonated apatites prepared at controlled pH and temperature. J Colloid Interface Sci. 1989;130(2):467-79.

Ngo W, Lucas Y, Clément A, Fritz B. Modeling the impact of temperature on the saturation state and behavior of minerals in the soultz-sous-forêts geothermal system. Geothermics. 2016;64:196-208.

Palandri JL, Kharaka YK. A compilation of rate parameters of water-mineral interaction kinetics for application to geochemical modeling. Technical report, Geological Survey Menlo Park CA; 2004.

Portier S, Vuataz FD. Developing the ability to model acid-rock interactions and mineral dissolution during the rma stimulation test performed at the soultz-sous-forêts egs site, france. Comptes Rendus Geosci. 2010;342(7-8):668-75.

Portier S, Vuataz F-D, Nami P, Sanjuan B, Gérard A. Chemical stimulation techniques for geothermal wells: experiments on the three-well egs system at soultz-sous-forêts, france. Geothermics. 2009;38(4):349-59.

Pribnow D, Schellschmidt R. Thermal tracking of upper crustal fluid flow in the rhine graben. Geophys Res Lett. 2000;27(13):1957-60.

Pribnow D, Clauser C. Heat and fluid flow at the soultz hot dry rock system in the rhine graben. In: World geothermal congress, Kyushu-Tohoku, Japan; 2000. p. 3835-3840

Rose P, XU T, Kovac K, Mella M, Pruess K. Chemical stimulation in near-wellbore geothermal formations: silica dissolution in the presence of calcite at high temperature and high pH. In: Proceedings of thirty-second workshop on geothermal reservoir engineering, Stanford University, Stanford, California; 2007.

Sausse J, Fourar M, Genter A. Permeability and alteration within the soultz granite inferred from geophysical and flow log analysis. Geothermics. 2006;35(5):544-60.

Sausse J, Dezayes C, Dorbath L, Genter A, Place J. $3 \mathrm{~d}$ model of fracture zones at soultz-sous-forêts based on geological data, image logs, induced microseismicity and vertical seismic profiles. Comptes Rendus Geosci. 2010;342(7):531-45.

Schellschmidt $\mathrm{R}$, Clauser $\mathrm{C}$. The thermal regime of the upper rhine graben and the anomaly at soultz. Zeitschrift für Angewandte Geologie. 1996;42:40-4.

Sekioka M. 25. Japanese geothermal waters throughout history. Stories Heated Earth Geotherm Herit. 1999;1 9:393.

Stillings LL, Brantley SL. Feldspar dissolution at $25 \mathrm{C}$ and pH 3: reaction stoichiometry and the effect of cations. Geochim Cosmochim Acta. 1995;59(8):1483-96.

Stober I, Bucher K. Hydraulic and hydrochemical properties of deep sedimentary reservoirs of the Upper Rhine Graben, Europe. Geofluids. 2015;15(3):464-82.

Takaya Y. Which constituent mineral is dominant in granite weathering? A solution-sided approach through a laboratory experiment. Geoderma. 2014;230:204-11.

Tester J, Brown D, Potter R. Hot dry rock geothermal energy_-a new energy agenda for the twenty-first century. Technical report, Los Alamos National Lab., NM (USA); 1989

Tester JW, Anderson BJ, Batchelor AS, Blackwell DD, DiPippo R, Drake E, Garnish J, Livesay B, Moore MC, Nichols K, et al. The future of geothermal energy: impact of enhanced geothermal systems (EGS) on the United States in the 21st century. Massachusetts Institute of Technology. 2006;209.

Thomas RL, Nasr-El-Din HA, Lynn JD, Mehta S, Zaidi SR. Precipitation during the acidizing of a HT/HP illitic sandstone reservoir in eastern saudi arabia: A laboratory study. In: SPE Annual Technical Conference and Exhibition. Society of Petroleum Engineers; 2001. https://doi.org/10.2118/71690-ms.

Tulinius $\mathrm{H}$, Correia H, Sigurdsson O. Stimulating a high enthalpy well by thermal cracking. In: World geothermal congress. 2000.

Zafar IZ, Ansari TM, Ashraf M, Abid MA. Effect of hydrochloric acid on leaching behavior of calcareous phosphorites. Iran J Chem Chem Eng. 2006;25(2):47-57.

Zimmermann G, Blöcher G, Reinicke A, Brandt W. Rock specific hydraulic fracturing and matrix acidizing to enhance a geothermal system—concepts and field results. Tectonophysics. 2011;503(1-2):146-54.

\section{Publisher's Note}

Springer Nature remains neutral with regard to jurisdictional claims in published maps and institutional affiliations.

\section{Submit your manuscript to a SpringerOpen ${ }^{\circ}$ journal and benefit from:}

- Convenient online submission

- Rigorous peer review

- Open access: articles freely available online

- High visibility within the field

- Retaining the copyright to your article

Submit your next manuscript at $\boldsymbol{\nabla}$ springeropen.com 